\title{
Variations in temperate forest biomass ratio along three environmental gradients are dominated by interspecific differences in wood density
}

\section{Baptiste Kerfriden}

INRAE

\section{Bontemps Jean-Daniel}

Institut national de l'information geographique et forestiere

Leban Jean-Michel ( $\nabla$ jean-michel.leban@inrae.fr)

https://orcid.org/0000-0002-8998-6472

\section{Research}

Keywords: Biomass ratio, wood density, environmental gradients, water, soil richness, elevation, France, interspecific, intraspecific, variability, national forest inventory

Posted Date: May 13th, 2020

DOI: https://doi.org/10.21203/rs.3.rs-27539/v1

License: (9) This work is licensed under a Creative Commons Attribution 4.0 International License. Read Full License 


\section{Abstract}

\section{Background}

Biomass ratio (BR) is a forest state variable allowing the conversion of forest volume of growing stock into biomass. Despite huge intraspecific variation in wood density depending on the biotic and abiotic environments of tree growth, this variable is most often considered a tree species constant in $\mathrm{C}$ budgets. The aims were i) to identify variations in BR along decorrelated water, soil nutrition and elevation gradients, ii) to test for differences between broadleaved and conifer tree species in BR variations, and iii) to weight the contribution of interspecific and intraspecific diversity in BR variations.

Methods

Analyses were based on massive wood density measurements performed with an X-ray medical scanner on 54,700 tree cores collected in 2016 and 2017 on the spatially systematic plot sampling design of the French national forest inventory (NFI) program.

Results

BR variations along the three gradients were found significant. BR hence decreased by $73 \mathrm{~kg} . \mathrm{m}-3$ (conifers) and $126 \mathrm{~kg} \cdot \mathrm{m}-3$ (broadleaves) along a $180 \mathrm{~mm}$ gradient of soil water holding capacity (SWHC). It also increased by $153 \mathrm{~kg} . \mathrm{m}-3$ on average along the full gradient of soil basicity Index (SBI). A negative trend along elevation was also identified, with an average decrease by $155 \mathrm{~kg} . \mathrm{m}-3$ from 200 to $2000 \mathrm{~m}$ of elevation. Species distribution was found to be the main cause of BR variations along these gradients.

\section{Conclusions}

We report dependences of BR on both water $(-)$, nutrient availability $(+)$ and warmth $(+)$ gradients, more acute in broadleaves than in conifers only for water availability. At the scale of the whole French forests, intraspecific variations in wood density do not affect BR estimations along these gradients. BR variations are mainly driven by the tree stand species composition along them.

\section{Background}

The need to limit global warming to $1.5^{\circ} \mathrm{C}$ (IPCC 2018) gives forests a major role to play in sequestrating $\mathrm{CO}_{2}$ (Pan et al. 2011), and requires sound knowledge on the components of forest biomass. Biomass ratio (BR) is the state variable of the forest identity (Kauppi et al. 2006) allowing for the conversion of standard forest volume of the growing stock into biomass, and it therefore plays a key role in forest carbon accounting. BR is defined as the community-weighted mean of the wood basic specific gravity $\left(G_{b}\right)$ that is the oven-dry weight divided by the green volume (Glass and Zelinka, 2010). $G_{b}$ is a standard desirable reference used for accounting forests biomass and for the comparison between species. Indeed, as for wood, both mass and volume depend on moisture content, the analysis of the wood density variability from the literature needs to be done with great care (Williamson and Wiemann 2010; 
Vieilledent et al. 2018). For convenience in the following we will use the generic expression "wood density" for both our measurements $\left(G_{b}\right)$ and the results from the literature that reports on wood density measured at varied wood moisture contents.

Since carbon accounting is performed over wide territories, BR has to be quantified over representative samples. In this respect, national forest inventories (NFI) have been implemented since the early 20th century (Tomppo et al. 2010) in order to assess forest resources and their changes over time, including the estimation of tree volumes. They hence form a primary support to systematic sampling of forest areas and mensuration attributes of their growing trees, and should play an increased role in these quantifications.

Due to high additional costs, wood density (WD) is however not routinely measured by NFI programs. Therefore, biomass estimates remain computed by combining tree volumes from NFIs and at best one average (WD) value per species. These values are extracted from existing wood density databases (Loustau et al. 2004, Dupouey 2002, Mathieu 1877 in France). In Europe, if for some countries, WD density values are not available, the IPCC 2006 recommendation are to use of the WD values published by Dietz (1975). For other continents several well-known WD data bases were published by Zanne et al. 2009, Chave et al. 2009 for global wood density database, Miles and Smith 2009 for north America, Carsan et al. 2012 for Africa. Also, despite their strong interest, the WD values from these data bases are not representative of the large tree populations existing within different national forest resources having variable growing conditions. The literature hence reports on the huge variability in WD, ranging from $100 \mathrm{~kg} / \mathrm{m}^{3}$ up to $1300 \mathrm{~kg} / \mathrm{m}^{3}$ across tree species as inferred from the Wood Density Database (Zanne et al. 2009; Chave et al. 2009). While more restricted than across tree species, intraspecific variations remain important. For instance Picea abies WD varies from 350 to $500 \mathrm{~kg} \cdot \mathrm{m}^{-3}$ (Trendelenburg and MayerWegelin 1955; Hakkila 1989) or from 650 to 850 kg.m ${ }^{-3}$ e.g. in Quercus petraea (Bergès et al. 2008; Bergès et al. 2000).

Availability in energy, water and nutrient resources is fundamental to forest ecosystem structure and function (Chapin et al. 1987; Reich et al. 2003). It may also play a role in the variability of WD across species and populations (nutrient and water resources in Chave et al. 2009; and temperature in Beets et al. 2007 and Filipescu et al. 2014). At the same time, wide gradients in the abiotic environment determine tree species distribution (Hacke and Sperry 2001; Markesteijn et al. 2011; Reich 2014), making the respective influences of inter- and intraspecific variability on the biomass ratio unclear, and prone to depend on spatial scale (Albert et al. 2011). Their quantification is thus a key to decide whether intraspecific variation can be ignored (Shipley et al. 2016). In tropical forests, studies have most often considered both sources of variation along elevation (Zhang and Yu 2018; Fajardo 2018), soil nutrient richness (Liu et al. 2012; Missio et al. 2016; Zhang and Yu 2018), and water availability (Hacke and Sperry 2001; Preston et al. 2006; Markesteijn et al. 2011; Reich 2014; Nunes Santos Terra et al. 2018). Nevertheless, few have pointed out to their respective contribution in WD along these gradients. By contrast, much more emphasis has been placed on single-species studies of WD (e.g. in Nothofagus pumilio in Fajardo 2018; Quercus petraea in Bergès et al. 2008; Pseudotsuga menziesii in Lassen and 
Okkonen 1969). The respective contributions of intra and interspecific levels on wood density variations therefore still needs relevant investigations.

With this respect, French forests are located in contrasted geologic (acidic to calcareous) and climatic conditions (Rameau et al. 1989), climates ranging from Mediterranean to continental. With over 150 forest tree species, specific diversity is also maximum in this country with respect to the European continent (Barbati et al. 2014; Bontemps et al. 2019). WD studies available over this territory are on monospecific stands and limited geographic areas of predominant tree species, including mainly Fagus sylvatica (Bouriaud et al. 2004; Bontemps et al. 2013), Quercus robur and petraea (Ackermann 1995; Guilley et al. 1999; Bergès et al. 2000), Picea abies (Bouriaud et al. 2005; Franceschini et al. 2012; Franceschini et al. 2013) or Pinus pinaster (Bouffier et al. 2008). In these publications WD variations are usually explained by the ring width and ring age variations and sometimes by including as well the effects of temperature and precipitation (Franceschini et al. 2013) or other site factors (Bergès et al. 2008). No reference describing interspecific variations in wood density in western European forests was identified, except an ancient compilation of WD measurements (Mathieu 1877).

In a context where accounting for carbon is a more recent addition to national forest inventories, a systematic collection of tree cores over the French NFI was engaged in 2016 (Leban et al. 2016) in order to perform massive wood density measurements with an X-ray medical scanner (Jacquin et al. 2019). The associated database covers 125 tree species and includes 54,700 tree cores to date, making it possible to inquire BR responses across environmental gradients, and disentangle the respective contributions of inter- and intraspecific diversity on these responses. Coupled with the NFI information system, BR can be estimated over any stratum of these forests. Soil water holding capacity (SWHC) and soil basicity index (SBI), computed from NFI field measurements were considered as proxies for water and nutrient resources. Elevation as a proxy for temperature was also inquired in view of its wide gradient across the territory. Tree species diversity was described both at the scales of botanical classes and of tree species. Botanical classes distinguish conifer from broadleaved tree species, the heterogeneous wood of the latter potentially allowing greater wood density plasticity (amount and repartition of vessels and fibres) on environmental gradients (e.g. with hydraulic conduction Hacke and Sperry 2001).

The following questions were addressed:

(Q1) What are the variations in BR along elevation, water and nutrient richness gradients?

(Q2) Does BR in conifer and broadleaved species show responses of contrasted magnitude along these gradients?

(Q3) Do interspecific differences in wood density contribute to BR variations along these gradients, and to what extend intraspecific variability plays a role in these variations?

In addition to these three questions we would like to test the following hypothesis that numbered according to the previous questions: 
(H1.1) A decrease in BR with increasing soil water holding capacity (SWHC) is expected because of the existing cross-species relationship between wood density and drought tolerance (Hacke and Sperry 2001; Markesteijn et al. 2011; Reich 2014).

(H1.2) We expect an increase in BR with soil basicity index (SBI) as wood density increases with soil pH as reported for tropical forests (Liu et al. 2012; Missio et al. 2016).

(H1.3) A decrease in BR with elevation is expected even if variations in WD with elevation show contrasted results (i) decreases at intra- (Zhang and Yu 2018 on tropical broadleaves; Bergès et al. 2008 on Quercus petraea) and interspecific levels (Mankou et al. 2017), and (ii) non-significant relationship with elevation (Fajardo 2018; Michalec et al. 2016).

(H2) We hypothesize that along these gradients broadleaves will show a greater sensitivity in WD than conifers because of their greater plasticity in wood anatomy at the intraspecific (Aguilar-Rodriguez et al. 2006) and interspecific levels (Wheeler and Baas 2018).

(H3) We hypothesize that both interspecific and intraspecific variations in wood density would significantly affect BR variations along the gradients because the geographical scale considered (Albert et al. 2011).

\section{Methods}

\section{Data}

\section{Sampling and data collection}

Tree cores were collected during forest inventory operations, in the years 2016 and 2017 of this continuous (annual) systematic sampling process (Robert et al. 2010; Hervé 2016). Core sampling was performed on the living trees selected for measurements (1 out of 2 living trees) of the 10,200 NFI plots covering the French metropolitan forests. Increment cores were extracted at breast height with increment borers (diameter $4.3 \mathrm{~mm}$ ). In total, 54,700 increment cores were collected from 125 species, of which 66 species were sampled with more than 30 increment cores. About $32 \%$ of the cores are sampled from the bark to the pith (for the age of the trees), the rest of the cores having on average a length of $58 \%$ of the tree radius (see Supplementary material 1 ).

\section{Sample processing}

Core drying, X-ray measurements and computation of the average core density are detailed in Supplementary material 1 . The process led to obtain estimates of wood basic specific gravity for effective conversion of green volume into dry biomass. It varies from 200 to $1080 \mathrm{~kg} / \mathrm{m}^{3}$ across the full sample, and from $372 \mathrm{~kg} / \mathrm{m}^{3}$ for Pinus strobus to $875 \mathrm{~kg} / \mathrm{m}^{3}$ for Quercus ilex, on average across species.

\section{Imputation of wood density}


For reducing the NFI costs increments cores are not sampled on all the trees measured on a forest inventory plot. On each NFI plot the technicians select at least 2 trees per species and per each of the 5 DBH classes (IGN, 2019). Thus, based on this pairing process, WD values were imputed to $94.5 \%$ of the living trees measured for size and without sampled cores $(70,100)$. Other non-cored trees $(5.5 \%)$ were isolated and were therefore imputed with a country mean WD per tree species and diameter class.

\section{Biomass Ratio calculation}

The stem biomass of a tree was computed using the stem volume (fresh volume at an upper threshold diameter of $7 \mathrm{~cm}$ ) estimated with NFI volume equations including as predictors the circumference at breast height, total height and first tree branching height (IGN 2018) that is the height where occurs an abrupt change of diameter or form. Total stem biomass and volume were calculated for each plot.

Biomass ratio $\left(\mathrm{BR}, \mathrm{kg} \cdot \mathrm{m}^{-3}\right)$ was defined as the ratio between biomass per hectare on a plot and the total volume per hectare on the same plot (see Supplementary material 1). Using the statistical weights of NFI plots, BR could then be computed for any forest entity defined by common attributes across plots.

\section{Variables used for the analysis}

Environmental indicators derived from NFI data collection included: i) soil water holding capacity (SWHC) at $1 \mathrm{~m}$ depth computed from soil depth, texture and stoniness (Baize and Jabiol 1995; Baize 1988) as a proxy for soil water availability, that ranged from 5 to $180 \mathrm{~mm}$ over the full sample, ii) a plant bioindication of the soil basicity index (SBI) based on a vegetation survey as a proxy for soil richness (Rameau et al. 1989) varying from 1 (acid) to 11 (basic), and iii) the elevation ranging from class $300 \mathrm{~m}$ (200 to $400 \mathrm{~m}$ ) to over $2000 \mathrm{~m}$, as a proxy for temperature (see Supplementary material 2). Details on environmental indicators can be found in Supplementary material 3. BR results were split in two dominant botanical classes by applying a threshold of $50 \%$ of the canopy cover. If more than $50 \%$ of the canopy cover is obtain from broadleaved species, then the BR value is labelled "Broadleaves" and vice et versa for "Conifers".

Interspecific variability was assessed by using means of tree species WD and their average position over the gradients.

\section{Analyses}

The three environmental gradients were defined by ordinated categorical variables and treated as continuous variables. To quantify BR variations along the three environmental gradients (Q1, H1.1 to H1.3), we applied weighted linear regression, intended to account for sample size in the factor levels. To explore differences in these responses between conifer/broadleaved-dominated plots (Q2), weighted ANCOVA of BR against gradient and botanical classes (broadleaves and conifers) were fitted. In addition, a multiple linear regression was performed between BR and the three gradients in order to confirm the direction and significance of the different effects evidenced. 
The relative importance of interspecific/intraspecific sources of variations in WD was measured by a oneway ANOVA of WD against tree species. Intra and interspecific variability is illustrated in Table 1 for the main forest trees species (with more than 2000 cores each), 5 species with the highest average WD and another 5 with the lowest WD. Interspecific variation was measured by linear regression between mean species WD and their respective position along the gradient, weighted by the number of samples. Last, to test for the influence and significance of intra-specific variability in WD on BR responses, we calculated the BR with two different methods: BRm by using for each tree the species means of WD, to be compared to the initial BR defined above and named here BRi which is computed with one individual WD value per tree. The method was treated as a categorical variable. Weighted analyses of covariance (ANCOVA) of BR against each environmental gradient and the estimation method were then fitted to explore systematic method-driven differences in BR along the environmental gradients.

Table 1

Range of variation for basic specific gravity for the 10 main French forest tree. The number of cores is proportional to the volume occupied by the species in the forests resources

\begin{tabular}{|c|c|c|c|c|c|c|}
\hline $\begin{array}{l}\text { Botanical } \\
\text { class }\end{array}$ & Tree species & $\begin{array}{l}\text { Average } \\
\mathrm{kg} \cdot \mathrm{m}^{3}\end{array}$ & $\begin{array}{l}\text { Standard } \\
\text { deviation }\end{array}$ & $\begin{array}{l}\text { Confidence } \\
\text { interval } 95 \%\end{array}$ & $\begin{array}{l}\text { Coefficient of } \\
\text { variation }\end{array}$ & $\begin{array}{l}\text { Sample } \\
\text { size }\end{array}$ \\
\hline \multirow[t]{7}{*}{ Broadleaves } & $\begin{array}{l}\text { Quercus } \\
\text { pubescens }\end{array}$ & 721 & 75 & $574-868$ & 0,10 & 2738 \\
\hline & $\begin{array}{l}\text { Quercus } \\
\text { petraea }\end{array}$ & 645 & 71 & $506-784$ & 0,11 & 5397 \\
\hline & $\begin{array}{l}\text { Quercus } \\
\text { robur }\end{array}$ & 626 & 67 & $495-757$ & 0,11 & 6419 \\
\hline & $\begin{array}{l}\text { Carpinus } \\
\text { betulus }\end{array}$ & 622 & 41 & $542-702$ & 0,07 & 3737 \\
\hline & $\begin{array}{l}\text { Fagus } \\
\text { sylvatica }\end{array}$ & 608 & 46 & $518-698$ & 0,08 & 5376 \\
\hline & $\begin{array}{l}\text { Fraxinus } \\
\text { excelsior }\end{array}$ & 597 & 57 & $485-709$ & 0,10 & 2439 \\
\hline & $\begin{array}{l}\text { Castanea } \\
\text { sativa }\end{array}$ & 503 & 57 & $391-615$ & 0,11 & 2699 \\
\hline \multirow[t]{3}{*}{ Conifers } & $\begin{array}{l}\text { Pinus } \\
\text { sylvestris }\end{array}$ & 461 & 60 & $343-579$ & 0,13 & 2446 \\
\hline & Abies alba & 415 & 48 & $321-509$ & 0,12 & 2620 \\
\hline & Picea abies & 386 & 47 & $294-478$ & 0,12 & 2503 \\
\hline
\end{tabular}

Data were analysed under the R software (R Development Core Team 2011). 


\section{Results}

\section{BR variations along the three gradients and difference between broadleaves and conifers (Q1 and Q2)}

BR varied between 287 and $1010 \mathrm{~kg} / \mathrm{m}^{3}$ across NFI plots. Mean BR for broadleaf- (resp. conifer) dominated plots was $582 \mathrm{~kg} \cdot \mathrm{m}^{-3}$ (resp. $433 \mathrm{~kg} \cdot \mathrm{m}^{3}$ ). Correlations between the different gradients were null (between SBI and elevation, $p=0.28)$ to weakly negative between SWHC and elevation $\left(-0.14, p<10^{-}\right.$ $\left.{ }^{4}\right)$, and between SWHC and elevation $\left(-0.29, \mathrm{p}<10^{-4}\right)$.

Along the SWHC gradient, BR varied from 710 to $580 \mathrm{~kg} / \mathrm{m}^{3}$ (resp. from 480 to $410 \mathrm{~kg} / \mathrm{m}^{3}$ ) for broadleaf(resp. conifer-, Fig. 1a) dominated plots, and on average by $77 \mathrm{~kg} \cdot \mathrm{m}^{3}$ and $12 \%$, a non-significant decrease $(p=0.15, \mathrm{H} 1.1)$. The covariance analysis confirmed a weak interaction between the botanical class and this response, indicating a greater variation in BR along the SWHC gradient within in broadleaf-dominated plots $(p=0.06)(H 2)$. When this response was split by botanical classes, the mean intensity of this response became significant with $-0.56 \mathrm{~kg} / \mathrm{m}^{3} / \mathrm{mm}$ for broadleaves $\left(p<10^{-3}\right)$, and $-0.23 \mathrm{~kg} / \mathrm{m}^{3} / \mathrm{mm}$ for conifers $\left(p<10^{-2}, H 1.1\right)$.

Along the SBI gradient, BR increased and varied from $580 \mathrm{~kg} / \mathrm{m}^{3}$ (SBI class 1) to $690 \mathrm{~kg} / \mathrm{m}^{3}$ (SBI class 10) in broadleaves, and from $440 \mathrm{~kg} / \mathrm{m}^{3}$ to $510 \mathrm{~kg} / \mathrm{m}^{3}$ in conifers (Fig. $1 \mathrm{~b}$ ), with an average increase by $153 \mathrm{~kg} \cdot \mathrm{m}^{3}(32 \%)$ over the gradient $\left(\mathrm{p}<10^{-3}, \mathrm{H} 1.2\right)$. The covariance analysis showed an absence of interaction with the botanical class $(\mathrm{H} 2, \mathrm{p}=0.71)$.

Along the elevation gradient, BR was found to decrease on average from 617 to $462 \mathrm{~kg} / \mathrm{m}^{3}$ (25\%), corresponding to a magnitude of $+13 \mathrm{~kg} / \mathrm{m}^{3} / 100$ m elevation $\left(p<10^{-4}, \mathrm{H} 1.3\right)$. In broadleaves (resp. conifers), it ranged from 630 to $550 \mathrm{~kg} / \mathrm{m}^{3}$ (resp. 490 to $420 \mathrm{~kg} / \mathrm{m}^{3}$ ) at $1800 \mathrm{~m}$ elevation (Fig. 1c) extreme deviations due to very few plots). The covariance analysis again showed a non-significant interaction with the botanical class $(H 2, p=0.69)$.

The joint variation of BR along the three gradients was tested by a multiple linear regression model taking into account the interaction detected between SWHC and botanical class. The three effects and the interaction were found simultaneously significant and confirmed the possibility to disentangle their effects onto BR.

2. Effect of intraspecific and interspecific variations in WD on BR gradients (Q3)

\section{Interspecific variations in WD along the environmental gradients}

SWHC. Species means of WD showed a significant negative relationship $(-2.37 \mathrm{~kg} / \mathrm{m} 3 / \mathrm{mm} \mathrm{SWHC}, \mathrm{p}<$ $10^{-4}$ ) with SWHC (Fig. 2a), for both broadleaves and conifers, and consistent with BR variations along 
the gradient (Fig. 1a).

$S B I$. Along the SBI gradient (Fig. 2b), mean WD revealed a significant positive relationship $(11.62 \mathrm{~kg} / \mathrm{m} 3 /$ unity of $\mathrm{SBI}, \mathrm{p}<0.05)$, with greater WD located on more basic soils on average, consistent with $B R$ variations along SBI (Fig. 1b).

Elevation. A non-significant negative cross-species relationship between mean WD and mean elevation was found ( $-0.04 \mathrm{~kg} / \mathrm{m} 3 / \mathrm{m}, \mathrm{p}=0.21)$ (Fig. 2c).

\section{Sensitivity of BR to intraspecific variability in WD along the gradients}

A one-way ANOVA of WD against tree species showed that interspecific variation predominated over intraspecific variation across the 125 species $\left(R^{2}=73 \%\right)$. For 10 most sampled tree species, the coefficient of variation of WD varied from $7-13 \%$, with a comparable order of magnitude across tree species (Table 1).

The sensitivity of BR estimation to intraspecific variability in wood density was systematically checked. The effect of the estimation method (BRi and BRm) was tested in both regression models, under its additive and interactive forms. Whatever the gradient (Fig. 3), no systematic deviation between the two methods was evidenced (Table 2). As a conclusion, whether intraspecific variations in wood density were accounted for in BR estimations had no effect on their grand averages, and variations along the three gradients.

Table 2

Regression models of Biomass Ratio against the three gradients with testing the effect of BR estimation method (BRi and BRm)

\begin{tabular}{|llll|}
\hline $\begin{array}{l}\text { Regression } \\
\text { model }\end{array}$ & Gradients & SBI & ELEVATION \\
\cline { 2 - 4 } & SWHC & SBI & no interaction $(p=0,57)$ \\
\hline $\begin{array}{l}\text { gradient } x \\
\text { methods }\end{array}$ & no interaction $(p=0,77)$ & no interaction $(p=0,83)$ & $\begin{array}{l}\text { no methods effect }(p= \\
0,90)\end{array}$ \\
\hline $\begin{array}{l}\text { gradient }+ \\
\text { methods }\end{array}$ & $\begin{array}{l}\text { no methods effect }(p=0,88) \\
0,85)\end{array}$ & \begin{tabular}{l} 
no methods effect $(p=$ \\
\hline
\end{tabular}
\end{tabular}

\section{Discussion}

Biomass ratio is a fundamental metrics to convert forest volume of the growing stock into biomass, and may depend on the abiotic environment. The major aims of this study were to identify 1) how BR varies along major environmental gradients defined by soil water content, soil nutrition, and elevation, 2) possible differences between broadleaves and conifers, 3) whether tree species contribute to feature the observed BR gradients and whether intraspecific variability in wood density must be accounted for in BR estimation. 
1.

BR variations along the three gradients (Q1) and differences between broadleaves and conifers (Q2)

We showed that BR decreased significantly with SWHC for both broadleaf- and conifer- dominated plots (Fig. 1a, H1.1). This pattern was consistent with the reported positive trait association of drought tolerance with species WD. This relationship has been mainly studied in tropical and subtropical forests (Hacke and Sperry 2001; Preston 2006; Markesteijn 2011; Reich 2014; Nunes Santos Terra 2018), with resistance to cavitation in drier conditions implying lower lumen size and greater wood density (Preston et al. 2006). However few studies have been carried out in temperate forests (Zanne et al. 2006; Hoffmann et al. 2011) where seasonality and different anatomical features (smaller conduit diameter in diffuse porous and ring-porous species) are specific to this environment (McCullow et al. 2010). No study on the relationship between WD and drought tolerance was found for European species. Therefore, the finding that BR gradient is more intense in broadleaves is an original result of this study, and supports the idea that a more plastic wood anatomy leads to gradient-driven acclimation processes (Martínez-Cabrera et al. 2017).

BR showed a significant increase along the SBI gradient (Fig. 1b, H1.2). Very few studies have explored the impact of soil acidity on WD among and within tree species. Liu et al. (2012) found a decreasing trend in WD with increasing soil acidity. While no study provides interpretation for this reported effect on wood density, soil acidity is known to impact nutrient concentration in the soil, in particular in Ca and Mg concentrations (Van der heijden et al. 2011; Jonard et al. 2012; Rowley et al. 2018) which are essential to photosynthesis (Masuda 2008) and wood structure (Ca ensures cationic bounds with pectin molecules in the cellular wall; Grant et al. 1973). Reduction in these nutrients' availability may thus affect wood formation and wood density. The universality of wood chemical composition (Savidge 2008) may account for the absence of difference in BR between broadleaves and conifers.

We found a significant decrease in BR with elevation (Fig. 1C, H1.3). In Mankou et al. 2017, species mean wood density inquired over a more restricted gradient (500 to 1000 meters) also showed a decrease with elevation (Fig. 2). The slight increase at the end of the gradient (Fig. 1) could be explained by species with greater wood density (i.e. Larix decidua for conifers), due to narrower conduit diameter (Preston et al. 2006) to avoid freezing-induced cavitation (Hacke and Sperry 2001; Davis et al. 1999a).

\section{Interspecific Variations In Wd Along The Environmental Gradients (Q3)}

Water gradient. In tropical forests, the interspecific variation in WD has been described as an adaptation to drought conditions (Hacke and Sperry 2001). To test for this relationship, we looked at the correlation between species drought tolerance index (Niinemets and Valladares 2006) and wood density which was found significant (Table 3). The correlation between drought tolerance index and SWHC of each species was also significant, showing that species distribution was in accordance with their ecological niches.

Page $10 / 23$ 
Table 3

Correlation between functional traits and wood density, and between functional trait and the gradients. * $\mathrm{p}<0.05, * \star \mathrm{p}<0.01, * \star \star \mathrm{p}<0.001$

\begin{tabular}{|lllll|}
\hline Gradient & $\begin{array}{l}\text { BR - Gradients } \\
\text { relationships }\end{array}$ & Functional trait associated & $\begin{array}{l}\text { Functional trait - } \\
\text { Wood density }\end{array}$ & $\begin{array}{l}\text { Functional trait } \\
\text { - Gradients }\end{array}$ \\
\hline SWHC & - & $\begin{array}{l}\text { Drought tolerance } \\
\text { (Niinemets and Valladares) }\end{array}$ & $0,45^{\star \star \star}$ & $-0,41^{\star \star \star}$ \\
\hline $\mathrm{SBI}$ & + & $\begin{array}{l}\text { Acidity preference (Gegout } \\
\text { et al.) }\end{array}$ & $0,29^{\star}$ & $0,66^{\star \star \star}$ \\
\hline Elevation & - & $\begin{array}{l}\text { Cold tolerance (Laanisto } \\
\text { and Niinemets) }\end{array}$ & $-0,19\left(^{*}\right)$ & 0,13 \\
\hline
\end{tabular}

Soil richness gradient. Along the SBI gradient, WD was found to increase across species, a relationship consistent with other studies (e.g. Liu et al. 2012). A significant correlation (Table 3) was found between acidity preference (functional trait from the ECOPLANT database, Gégout et al. 2005) and wood density which, consistent with our findings regarding species distribution along the SBI gradient. We also found a significant and consistent correlation between this functional trait and SBI of each species.

Elevation gradient. At the interspecific level, we found a decrease in WD with elevation which is consistent with other studies (e.g. Mankou et al. 2017). We found a significant $(p<10-4)$ correlation of +0.7 between elevation and mean annual temperature (see Supplementary material 2) making elevation a good indicator for temperature variation. To test for the possible effect of colder temperature on interspecific variation of WD, we used a cold tolerance index (from 0 to 5 ) as a functional trait for each species, which is based on yearly minimum temperature of species habitat (Laanisto and Niinemets 2015). We found a weak correlation (Table 3 ) between cold tolerance and WD, and a non-significant one between cold tolerance and the mean elevation of each species. Therefore cold tolerance cannot explain interspecific variation of WD. To better understand why the WD density trend is negative, additional analysis are necessary at the more focused scale, for instance, at the tree and species level for wood anatomical measurements, tracheid lumens, occurrence of compression wood, tree ages and size. These investigations are possible as all the selected cores are stored and available for additional measurements.

\section{Sensitivity of BR to intraspecific variability in WD along the gradients (Q3)}

We found that computed BR with tree species means of WD (BRm, Fig. 3) yielded the same BR estimates (Table 2) as those computed with individual tree core measurements (BRi). In this sense, intraspecific variability in WD did not influence BR which is driven by the range of variation of the interspecific variability thus invalidating hypothesis $\mathrm{H} 3$ at the scale of the whole forest resources. These results confirm Albert et al. (2011) theory on interspecific variability turning more important than intraspecific variability with increasing spatial scale. On the contrary, intraspecific variability (Table 1) was much greater than that accounted for by the gradients (data not presented, $\mathrm{R}^{2}=2.7 \%$ on average on the three gradients, and varying from $0.2-9.5 \%$ ). This suggested that other effects including tree developmental 
stage (Franceschini et al. 2013; Guilley et al. 2004) or genetics, and not captured in this study, may have a strong influence on this variability. Species distribution over a gradient was found in strong accordance with its environmental preferences (Shipley et al. 2016), with greater abundance on one position on the gradient where species fitness is at its best. This finding echoes questions raised by Shipley et al. (2016): "When can intraspecific trait variation be safely ignored and when must it be included? For which traits is this true? Along which environmental gradients?" WD has been previously identified as a conservative plant trait, with limited intraspecific variation at large scale (Siefert et al. 2015) compared to other functional traits. On the contrary, specific leaf area for example have been described as way more variable at the intraspecific level (Shipley 2000b), and may not need the same treatment in ecological analysis.

With ongoing climate change yielding warmer and drier climates, change in BR would also primarily result from shifts in plant community structure, i.e. changes in abundance or position of tree species along the gradients of SWHC and elevation. Due to the negative relationships evidenced between BR and water and elevation gradients, greater BR are anticipated to be encountered in a warmer and drier future. What the extent of such increase may be, and whether declines in tree growth (as already detected in France, Charru et al. 2017) would offset this increase. Such results pave the avenue for new stimulating research questions.

\section{Conclusions}

In this work we have analysed the variations in biomass ratio across gradients of water and nutrient availability and elevation in temperate forests of Western Europe and found the main following results:

- For broadleaved and coniferous dominated plots we found significant relationships between BR and water $(-)$, soil richness $(+)$ and elevation $(-)$ gradients

- Intensity of this relationship along the water gradient differed between broadleaves and conifers, but were found similar with the two other gradients.

- BR gradients were strongly structured by tree species distribution, those with greatest/lowest BR occupying opposed positions on any of these environmental gradients. Species distribution was found correlated to its adaptation to water, temperature and mineral availability.

- At the scale of whole the French forests resources the calculation of the BR variations along these three gradients can be safely obtained by accounting for the interspecific WD.

- These results demonstrate the strong interest to analyse the huge amount of data produced by the French NFI and provide a sound support for future investigations at different and lower spatial scales for which the intra specific WD variations would be necessary. Further studies could also investigate how BR varies with forest management (monospecific stands vers mixed stands, rotation age). At last, investigating the temporal scale is another perspective as our new data set would permit the analysis of the biomass increments along the envirenmental gradients. 


\section{List Of Abbreviations}

\begin{tabular}{|ll|}
\hline Abbreviation & Meaning \\
\hline BR & Biomass ratio \\
\hline NFI & National Forest Inventory \\
SWHC & Soil Water Holding Capacity \\
SBI & Soil Basicity Index \\
WD & Wood Density \\
\hline
\end{tabular}

\section{Declarations}

\section{Ethics approval and consent to participate}

Not applicable

\section{Consent for publication}

Not applicable

\section{Availability of data and materials}

The datasets generated and analysed during the current study are not fully publicly available: part of them are in the SM material while the other part is under embargo until the publication of other scientific papers including data papers

\section{Competing interests}

The authors declare that they have no competing interests

\section{Funding}

This work was supported by the Agence Nationale de l'Environnement et de la Maîtrise de l'Energie (ADEME), by the Region Grand Est, the LabEx ARBRE and the French Ministry of Agriculture, convention $n^{\circ} \mathrm{A} 6.01 / 2017$

\section{Authors' contributions}

BK did the analysis. BK, JDB and JML wrote the manuscript. JDB and JML supervised the research carried out by BK for his PhD.

\section{Acknowledgements}


This paper is dedicated to Jean-Christophe Herve the former scientific director of the French NFI who passed away in 2017. JCH and JML conceive and launched the XyloDensMap project in October 2015.

Special thanks to the French National Forest Inventories staff for collecting the increment cores and performing the field measurements on the forest plots and to the Xylosciences platform (INRAE Champenoux) team for the CT scanning.

The data base used for this analysis was built with the assistance of our colleagues from the French National Forest Inventory Service (SIFE at Nogent/Vernisson IGN), Cédric Duprez, Vincent Dauffy, François Morneau, Thierry Touzet, Stéphanie Wurpillot and our colleagues from Champenoux (INRAE) for the wood density measurements, Antoine Billard, Angèle Taravella, Sanjoy Roy, Emmanuel Cornu, Maryline Haroué, Philippe Jacquin, Maxime Lacarin, Charline Mola, Adeline Motz, Amélie Taupin and Lucile Savagner.

\section{References}

1. Ackermann, F. (1995). Influence du type de station forestière sur les composantes intracernes de la densité du bois du chêne pédonculé (Quercus robur L) dans les chênaies de l'Adour et des coteaux basco-béarnais. In Annales des sciences forestières (Vol. 52, No. 6, pp. 635-652). EDP Sciences.

2. Aguilar-Rodríguez, S., Terrazas, T., \& López-Mata, L. (2006). Anatomical wood variation of Buddleja cordata (Buddlejaceae) along its natural range in Mexico. Trees, 20(2), 253.

3. Albert, C. H., Grassein, F., Schurr, F. M., Vieilledent, G., \& Violle, C. (2011). When and how should intraspecific variability be considered in trait-based plant ecology?. Perspectives in Plant Ecology, Evolution and Systematics, 13(3), 217-225.

4. Baize, D., \& Jabiol, B. (1995). Guide pour la description des sols. Quae.

5. Baize, D. (1988). Guide des analyses courantes en pédologie. Institut national de la recherche agronomique.

6. Barbati, A., Marchetti, M., Chirici, G., \& Corona, P. (2014). European forest types and forest Europe SFM indicators: tools for monitoring progress on forest biodiversity conservation. Forest Ecology and Management, 321, 145-157.

7. Beets, P. N., Kimberley, M. O., \& McKinley, R. B. (2007). Predicting wood density of Pinus radiata annual growth increments. New Zealand Journal of Forestry Science, 37(2), 241.

8. Bergès, L., Dupouey, J. L., \& Franc, A. (2000). Long-term changes in wood density and radial growth of Quercus petraea Liebl. in northern France since the middle of the nineteenth century. Trees, 14(7), 398-408.

9. Bergès, L., Nepveu, G., \& Franc, A. (2008). Effects of ecological factors on radial growth and wood density components of sessile oak (Quercus petraea Liebl.) in Northern France. Forest Ecology and Management, 255(3-4), 567-579. 
10. Bontemps, J. D., Gelhaye, P., Nepveu, G., \& Hervé, J. C. (2013). When tree rings behave like foam: moderate historical decrease in the mean ring density of common beech paralleling a strong historical growth increase. Annals of forest science, 70(4), 329-343.

11. Bontemps, J. D., Hervé, J. C., \& Denardou, A. (2019). Partition idéalisée et régionalisée de la composition en espèces ligneuses des forêts françaises. Écoscience, 1-18.

12. Bouffier, L., Rozenberg, P., Raffin, A., \& Kremer, A. (2008). Wood density variability in successive breeding populations of maritime pine. Canadian journal of forest research, 38(8), 2148-2158.

13. Bouriaud, O., Bréda, N., Le Moguedec, G., \& Nepveu, G. (2004). Modelling variability of wood density in beech as affected by ring age, radial growth and climate. Trees, 18(3), 264-276.

14. Bouriaud, O., Leban, J. M., Bert, D. \& Deleuze, C., (2005). Intra-annual variations in climate influence growth and wood density of Norway spruce. Tree physiology, 25(6), pp. 651-660.

15. Carsan, S., Orwa, C., Harwood, C., Kindt, R., Stroebel, A., Neufeldt, H., \& Jamnadass, R. (2012). African wood density database. World Agroforestry Centre, Nairobi.

16. Chapin, F. S., Bloom, A. J., Field, C. B., \& Waring, R. H. (1987). Plant responses to multiple environmental factors. Bioscience, 37(1), 49-57.

17. Charru, M., Seynave, I., Hervé, J. C., Bertrand, R., \& Bontemps, J. D. (2017). Recent growth changes in Western European forests are driven by climate warming and structured across tree species climatic habitats. Annals of Forest Science, 74(2), 33.

18. Chave, J., Coomes, D., Jansen, S., Lewis, S. L., Swenson, N. G., \& Zanne, A. E. (2009). Towards a worldwide wood economics spectrum. Ecology letters, 12(4), 351-366.

19. Davis, S. D., Sperry, J. S., \& Hacke, U. G. (1999). The relationship between xylem conduit diameter and cavitation caused by freezing. American journal of botany, 86(10), 1367-1372.

20. Dietz, P. (1975). Dichte und Rindengehalt von Industrieholz. Holz als Roh-und Werkstoff, 33(4), 135141.

21. Dupouey, JL, (2002). Estimation de la densité du bois pour les espèces ligneuses de la flore de France à partir d'une synthèse bibliographique. Unpublished work.

22. Eklund, L., \& Eliasson, L. (1990). Effects of Calcium Ion Concentration on Cel Wall Synthesis. Journal of Experimental Botany, 41(7), 863-867.

23. Fajardo, A. (2018). Insights into intraspecific wood density variation and its relationship to growth, height and elevation in a treeline species. Plant Biology, 20(3), 456-464.

24. Filipescu, C. N., Lowell, E. C., Koppenaal, R., \& Mitchell, A. K. (2013). Modeling regional and climatic variation of wood density and ring width in intensively managed Douglas-fir. Canadian journal of forest research, 44(3), 220-229.

25. Franceschini, T., Bontemps, J. D., \& Leban, J. M. (2012). Transient historical decrease in earlywood and latewood density and unstable sensitivity to summer temperature for Norway spruce in northeastern France. Canadian Journal of Forest Research, 42(2), 219-226. 
26. Franceschini, T., Bontemps, J. D., Perez, V., \& Leban, J. M. (2013). Divergence in latewood density response of Norway spruce to temperature is not resolved by enlarged sets of climatic predictors and their non-linearities. Agricultural and forest meteorology, 180, 132-141.

27. Gégout, J. C., Coudun, C., Bailly, G., \& Jabiol, B. (2005). EcoPlant: a forest site database linking floristic data with soil and climate variables. Journal of Vegetation Science, 16(2), 257-260.

28. Glass, S. V., and S. L. Zelinka. 2010. Moisture relations and physical properties of wood. In Wood handbook: wood as an engineering material, 4-1-19. General Technical Report FPL-GTR-190. U.S. Dept. of Agriculture, Forest Service, Forest Products Laboratory, Madison, WI, USA.

29. Grant, G. T., Morris, E. R., Rees, D. A., Smith, P. J., \& Thom, D. (1973). Biological interactions between polysaccharides and divalent cations: the egg-box model. FEBS letters, 32(1), 195-198.

30. Guilley, É., Hervé, J. C., Huber, F., \& Nepveu, G. (1999). Modelling variability of within-ring density components in Quercus petraea Liebl. with mixed-effect models and simulating the influence of contrasting silvicultures on wood density. Annals of Forest Science, 56(6), 449-458

31. Guilley, E., Hervé, J. C., \& Nepveu, G. (2004). The influence of site quality, silviculture and region on wood density mixed model in Quercus petraea Liebl. Forest Ecology and Management, 189(1-3), 111-121.

32. Hacke, U. G., \& Sperry, J. S. (2001). Functional and ecological xylem anatomy. Perspectives in plant ecology, evolution and systematics, 4(2), 97-115.

33. Hakkila, P. (1989). Utilization of residual forest biomass. In Utilization of residual forest biomass (pp. 352-477). Springer, Berlin, Heidelberg.

34. Hervé JC. (2016) France. In: Vidal C., Alberdi I., Hernández Mateo L., Redmond J. (eds) National Forest Inventories. Springer, Cham.

35. Hoffmann, W. A., Marchin, R. M., Abit, P., \& Lau, O. L. (2011). Hydraulic failure and tree dieback are associated with high wood density in a temperate forest under extreme drought. Global Change Biology, 17(8), 2731-2742.

36. IGN (2018). Les tarifs de cubage de l'Inventaire forestier national depuis 2005. Unpublished work.

37. IGN (2019). Méthodologie. Pour bien comprendre les résultats publiés 2014-2019, 38 pages.

38. https://inventaire-forestier.ign.fr/IMG/pdf/191023-methodologie_v2.pdf

39. IPCC, R., \& Revised, I. E. A. (2006). IPCC guidelines for national greenhouse gas inventories. Prepared by the National Greenhouse Gas Inventories Programme, 10 - 1.

40. IPCC (2018). Summary for Policymakers. In: Global Warming of $1.5^{\circ} \mathrm{C}$. An IPCC Special Report on the impacts of global warming of $1.5^{\circ} \mathrm{C}$ above pre-industrial levels and related global greenhouse gas emission pathways, in the context of strengthening the global response to the threat of climate change, sustainable development, and efforts to eradicate poverty [Masson-Delmotte, V., P. Zhai, H.-O. Pörtner, D. Roberts, J. Skea, P.R. Shukla, A. Pirani, W. Moufouma-Okia, C. Péan, R. Pidcock, S. Connors, J.B.R. Matthews, Y. Chen, X. Zhou, M.I. Gomis, E. Lonnoy, T. Maycock, M. Tignor, and T. Waterfield (eds.)]. World Meteorological Organization, Geneva, Switzerland, 32 pp 
41. Jacquin, P., Mothe, F., Longuetaud, F., Billard, A., Kerfriden, B., \& Leban, J. M. (2019). CarDen: A software for fast measurement of wood density on increment cores by CT scanning. Computers and Electronics in Agriculture, 156, 606-617.

42. Jonard, M., Legout, A., Nicolas, M., Dambrine, E., Nys, C., Ulrich, E., ... \& Ponette, Q. (2012). Deterioration of $\mathrm{N}$ orway spruce vitality despite a sharp decline in acid deposition: a long-term integrated perspective. Global Change Biology, 18(2), 711-725.

43. Kauppi, P. E., Ausubel, J. H., Fang, J., Mather, A. S., Sedjo, R. A., \& Waggoner, P. E. (2006). Returning forests analyzed with the forest identity. Proceedings of the National Academy of Sciences, 103(46), 17574-17579.

44. Laanisto, L., \& Niinemets, Ü. (2015). Polytolerance to abiotic stresses: how universal is the shadedrought tolerance trade-off in woody species?. Global Ecology and Biogeography, 24(5), 571-580.

45. Lassen, L. E., \& Okkonen, E. A. (1969). SAPWOOD THICKNESS OF DOUGLAS-FIR AND FIVE OTHER WESTERN SOFTWOODS (No. FSRP-FPL-124). FOREST PRODUCTS LAB MADISON WIS.

46. Lautner, S., Ehlting, B., Windeisen, E., Rennenberg, H., Matyssek, R., \& Fromm, J. (2007). Calcium nutrition has a significant influence on wood formation in poplar. New Phytologist, 173(4), 743-752.

47. Leban, J. M., Hervé, J. C., Bontemps, J. D., Longuetaud, F., Mothe, F., Jacquin, P. (2016). Measurement of the annual biomass increment of the French forests - XYLODENSMAP project. In: IUFRO Working Parties 5.01.04 and 3.02.04 (WoodQc), 12-17 June 2016, Québec/Baie-St-Paul, Canada.

48. Liu, X., Swenson, N. G., Wright, S. J., Zhang, L., Song, K., Du, Y., ... \& Ma, K. (2012). Covariation in plant functional traits and soil fertility within two species-rich forests. PLoS one, 7(4), e34767.

49. Loustau, D., Déqué, M., Ciais, P., Davi, H., Badeau, V., Dupouey, J. L., ... \& Disnar, R. (2004). Séquestration de Carbone dans les grands écosystèmes forestiers en France. Quantification, spatialisation, vulnérabilité et impacts de différents scénarios climatiques et sylvicoles. In Rapport Final Projet GICC 2001" Gestion des impacts du changement climatique" et Convention Gip ECOFOR n 3/2001, Juin 2004, INRA, Bordeaux-Pierroton (France).

50. Mankou, G. S., Picard, N., Ngomanda, A., \& Loumeto, J. J. (2017). Co-variation in biomass and environment at the scale of a forest concession in central Africa. Journal of Tropical Ecology, 33(4), 249-260.

51. Markesteijn, L., Poorter, L., Bongers, F., Paz, H., \& Sack, L. (2011). Hydraulics and life history of tropical dry forest tree species: coordination of species' drought and shade tolerance. New Phytologist, 191(2), 480-495.

52. Martínez-Cabrera, H. I., Zheng, J., \& Estrada-Ruiz, E. (2017). Wood functional disparity lags behind taxonomic diversification in angiosperms. Review of Palaeobotany and Palynology, 246, 251-257.

53. Masuda, T. (2008). Recent overview of the Mg branch of the tetrapyrrole biosynthesis leading to chlorophylls. Photosyn. Res. 96, 121-143. doi: 10.1007/s11120-008-9291-4

54. Mathieu A ., (1877), Flore forestière, 3ème édition, Berger-Levrault, Paris, 618 p.

55. McCulloh, K., Sperry, J. S., Lachenbruch, B., Meinzer, F. C., Reich, P. B., \& Voelker, S. (2010). Moving water well: comparing hydraulic efficiency in twigs and trunks of coniferous, ring-porous, and 
diffuse-porous saplings from temperate and tropical forests. New Phytologist, 186(2), 439-450.

56. Michalec, K., Wasik, R., \& Barszcz, A. (2016). Variability of selected macrostructural features and density of Picea abies (L.) Karst. wood from lower and upper subalpine forest zones. SYLWAN, 160(10), 855-860.

57. Miles, P. D., \& Smith, W. B. (2009). Specific gravity and other properties of wood and bark for 156 tree species found in North America (Vol. 38). US Department of Agriculture, Forest Service, Northern Research Station.

58. Missio, F. D. F., Higuchi, P., Silva, A. C. D., Longhi, S. J., Salami, B., Dalla Rosa, A., ... \& Bento, M. A. (2016). Trade-offs and spatial variation of functional traits of tree species in a subtropical forest in southern Brazil. iForest-Biogeosciences and Forestry, 9(6), 855.

59. Niinemets, Ü., \& Valladares, F. (2006). Tolerance to shade, drought, and waterlogging of temperate Northern Hemisphere trees and shrubs. Ecological monographs, 76(4), 521-547.

60. Pan, Y., Birdsey, R. A., Fang, J., Houghton, R., Kauppi, P. E., Kurz, W. A., ... \& Ciais, P. (2011). A large and persistent carbon sink in the world's forests. Science, 333(6045), 988-993.

61. Preston, K. A., Cornwell, W. K., \& DeNoyer, J. L. (2006). Wood density and vessel traits as distinct correlates of ecological strategy in 51 California coast range angiosperms. New Phytologist, 170(4), 807-818.

62. R Development Core Team, R. F. F. S. C. (2011). R: A language and environment for statistical computing.

63. Rameau, J. C., Mansion, D., Dumé, G., Timbal, J., Lecointe, A., Dupont, P., \& Keller, R. (1989). Flore forestière française. Guide écologique illustré, 1, 1785.

64. Reich, P. B., Wright, I. J., Cavender-Bares, J., Craine, J. M., Oleksyn, J., Westoby, M., \& Walters, M. B. (2003). The evolution of plant functional variation: traits, spectra, and strategies. International Journal of Plant Sciences, 164(S3), S143-S164.

65. Reich, P. B. (2014). The world-wide 'fast-slow'plant economics spectrum: a traits manifesto. Journal of Ecology, 102(2), 275-301.

66. Robert N, Vidal C, Colin A, Hervé JC, Hamza N, Cluzeau C (2010) France. In: Tomppo E, Gschwantner T, Lawrence M, McRoberts RE (eds) National forest inventories-pathways for common reporting. Springer, Heidelberg, pp 207-221.

67. Rowley, M. C., Grand, S., \& Verrecchia, É. P. (2018). Calcium-mediated stabilisation of soil organic carbon. Biogeochemistry, 137(1-2), 27-49.

68. Savidge, R. A. (2008). Learning from the past-the origin of wood. The forestry chronicle, 84(4), 498503.

69. Shipley, B. (2000). Plasticity in relative growth rate and its components following a change in irradiance. Plant, Cell \& Environment, 23(11), 1207-1216.

70. Shipley, B., De Bello, F., Cornelissen, J. H. C., Laliberté, E., Laughlin, D. C., \& Reich, P. B. (2016). Reinforcing loose foundation stones in trait-based plant ecology. Oecologia, 180(4), 923-931. 
71. Siefert, A., Violle, C., Chalmandrier, L., Albert, C. H., Taudiere, A., Fajardo, A., ... \& de L. Dantas, V. (2015). A global meta-analysis of the relative extent of intraspecific trait variation in plant communities. Ecology letters, 18(12), 1406-1419.

72. Terra, M. D. C. N. S., Santos, R. M. D., Prado Júnior, J. A. D., de Mello, J. M., Scolforo, J. R. S., Fontes, M. A. L., ... \& ter Steege, H. (2018). Water availability drives gradients of tree diversity, structure and functional traits in the Atlantic-Cerrado-Caatinga transition, Brazil. Journal of Plant Ecology, 11(6), 803-814.

73. Tomppo, E., Gschwantner, T., Lawrence, M., McRoberts, R. E., Gabler, K., Schadauer, K., ... \& Cienciala, E. (2010). National forest inventories. Pathways for Common Reporting. European Science Foundation, 541-553.

74. Trendelenburg, R., \& Mayer-Wegelin, H. (1955). Das holz als rohstoff.

75. van der Heijden, G., Legout, A., Nicolas, M., Ulrich, E., Johnson, D. W., \& Dambrine, E. (2011). Longterm sustainability of forest ecosystems on sandstone in the Vosges Mountains (France) facing atmospheric deposition and silvicultural change. Forest Ecology and Management, 261(3), 730-740.

76. Wheeler, E. A., \& Baas, P. (2018). Wood evolution: Baileyan trends and Functional traits in the fossil record. IAWA journal, 1(aop), 2-42.

77. Zanne, A. E., Sweeney, K., Sharma, M., \& Orians, C. M. (2006). Patterns and consequences of differential vascular sectoriality in 18 temperate tree and shrub species. Functional Ecology, 20(2), 200-206.

78. Zanne, A. E., Lopez-Gonzalez, G., Coomes, D. A., Ilic, J., Jansen, S., Lewis, S. L., ... \& Chave, J. (2009). Global wood density database.

79. Zhang, Z., \& Yu, S. (2018). Potential tradeoffs between intraspecific and interspecific trait variations along an environmental gradient in a subtropical forest. Journal of forestry research, 29(6), 17311740 .

\section{Figures}




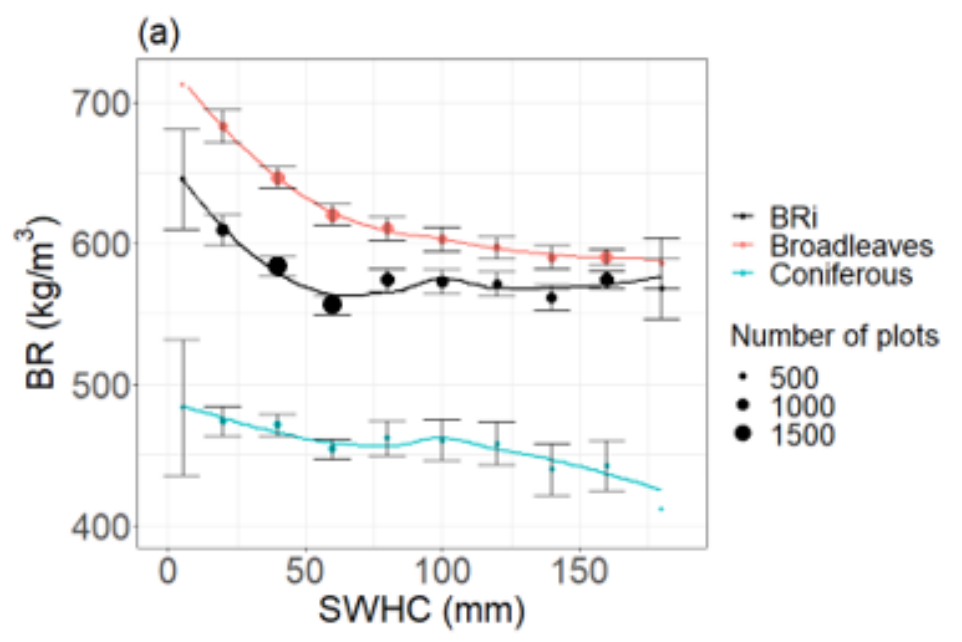

(b)

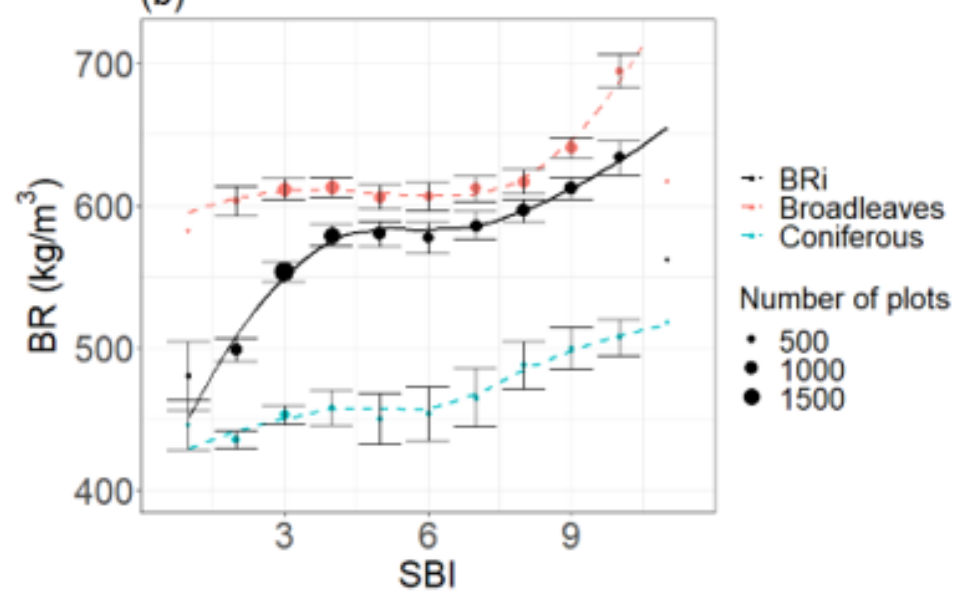

(c)

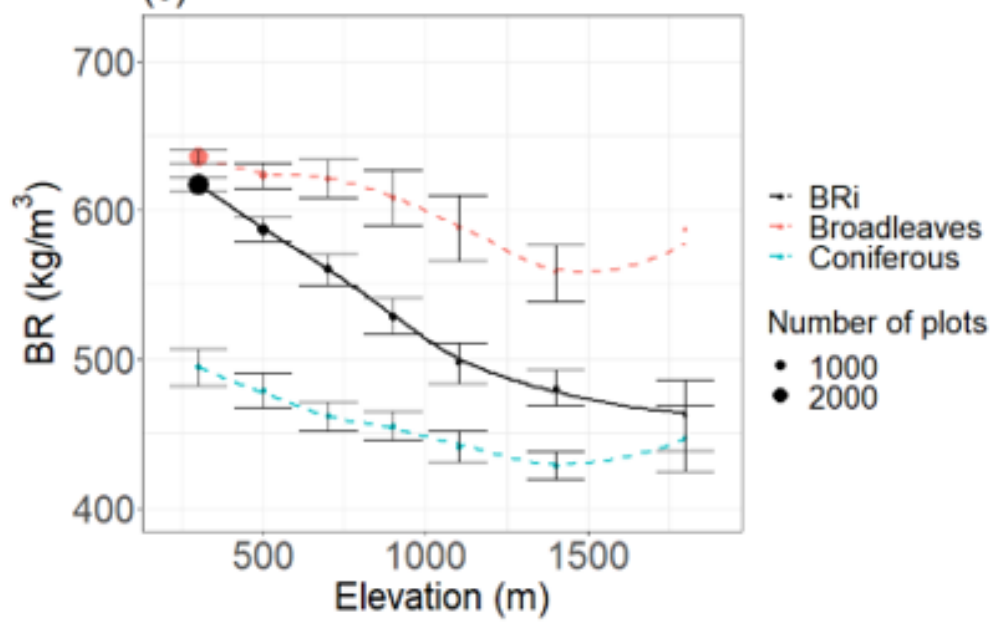

Figure 1

Relationships between BR and (a) SWHC, (b) SBI, and (c) Elevation in the French forests. SWHC in mm, $\mathrm{SBI}$ on a scale from 1 to 11 , Elevation in meters. (Dashed lines are used when there is not interaction between gradients and botanical class) 

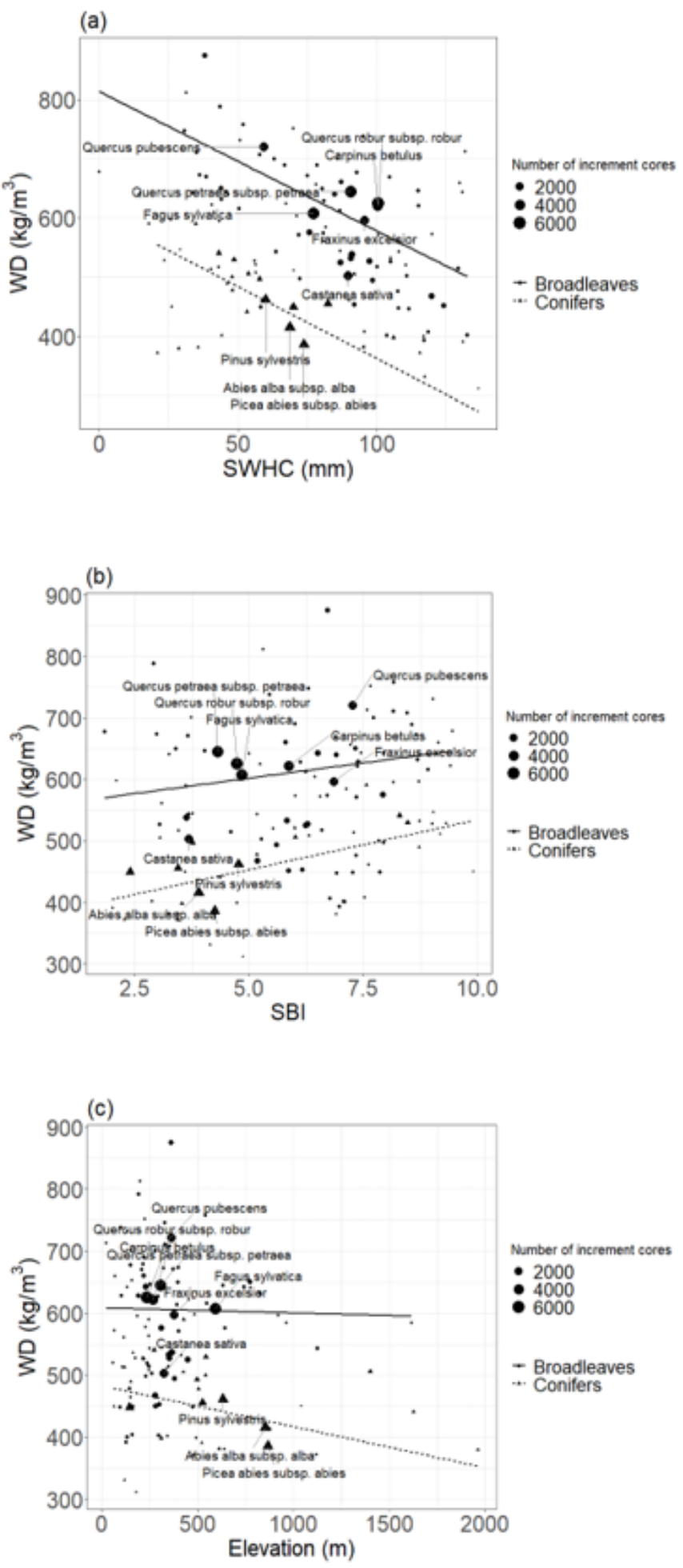

\section{Figure 2}

Tree species mean position along the gradients of (a) SWHC, (b) SBI and (c) elevation. 125 species were investigated: 91 broadleaves and 34 conifers. 

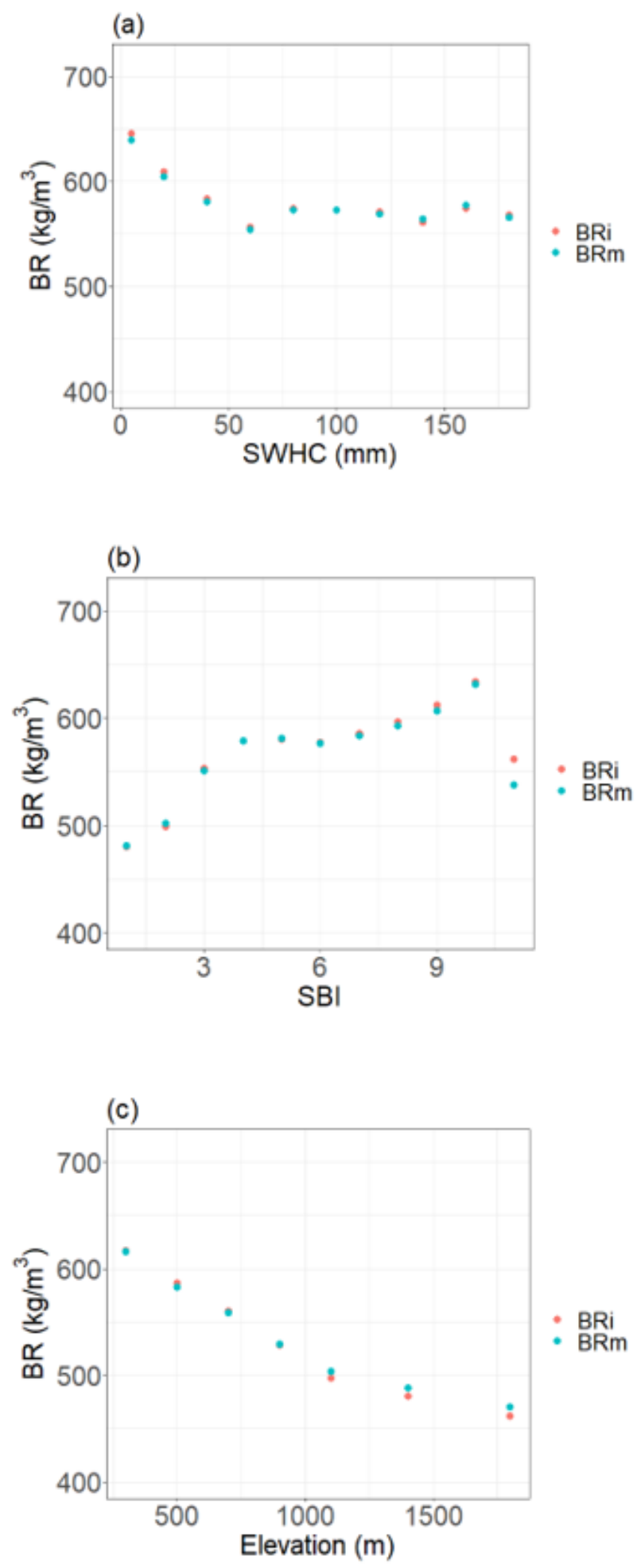

Figure 3

Relationships between BRi / BRm and the three environmental gradients under study. (a) SWHC in mm, (b) SBI on a scale from 1 to 11 (c) elevation in meters.

\section{Supplementary Files}


This is a list of supplementary files associated with this preprint. Click to download.

- SupplementaryMaterial1.docx 